
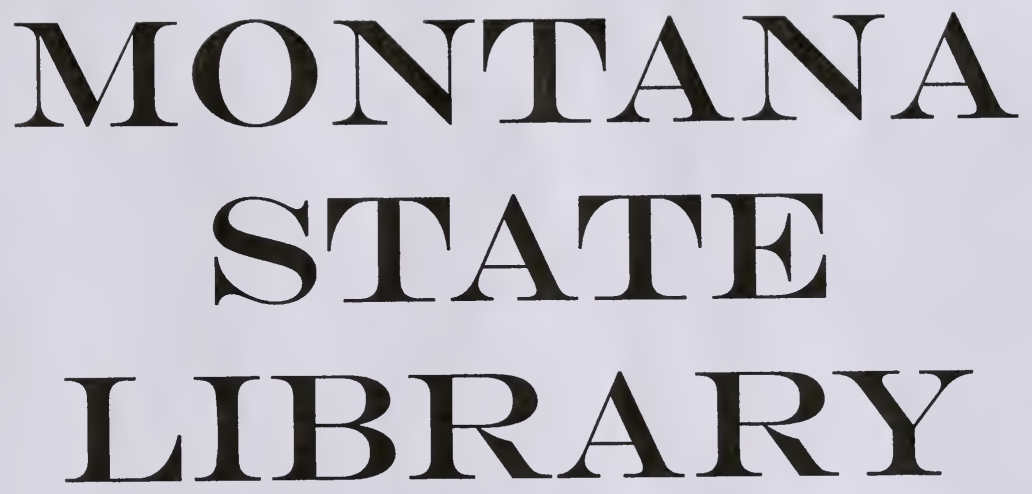

This "cover" page added by the Internet Archive for formatting purposes 


\section{- REPORT ON THE CONSERVATION STATUS OF SHOSHONEA PULVINATA, A CANDIDATE THREATENED SPECIES}

\author{
Taxon Name: \\ Common Name: \\ Family: \\ States Where Taxon Occurs: \\ Current Federal Status: \\ Recommended Federal Status: \\ Authors of Report: \\ Original Date of Report: \\ Date of Most Recent Revision: \\ Individual to Whom Further \\ Information and Comments \\ Should Be Sent:
}

Shoshonea pulvinata Evert \& Constance Shoshonea

Apiaceae (Umbelliferae)

U.S.A., Montana, Wyoming

USFWS Notice of Review, Category 2

USFWS Notice of Review, Category 2

Peter Lesica and J. Stephen Shelly

27 April, 1988

N/A

J. Stephen Shelly

Montana Natural Heritage Program

State Library Building

$1515 \mathrm{E}$. 6th Avenue

Helena, MT 59620

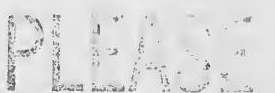




\section{This is an abridged report}

For the full report please contact:

The Montana Natural Heritage Program

1515 E Sixth Ave

Helena, Montana 59620

406-444-3009 
I. SPECIES INFORMATION

1. Classification and nomenclature

2. Present legal or other formal status

3. Description

4. Significance

5. Geographical distribution

6. General environment and habitat description 17

7. Population biology of the taxon

8. Population ecology of the taxon

9. Current land ownership and management responsibility

10. Management practices and experience

11. Evidence of threats to survival

II. ASSESSMENT AND RECOMMENDATIONS

12. General assessment of vigor, trends, and status

13. Recommendations for listing or status change

14. Recommended critical habitat

15. Conservation/recovery recommendations

16. Interested parties

III. INFORMATION SOURCES

17. Sources of information

18. Summary of materials on file

IV. AUTHORSHIP

19. Initial authorship

20. Maintenance of 5 tatus report

V. NEW INFORMATION

21. Record of revisions

LITERATURE CITED

APPENDIX A: Letter from Crow Tribal Council

APPENDIX B: Element occurrence print-outs: Montana 
I. SPECIES INFORMATION

1. Classification and nomenclature.

A. Species.

1. Scientific name.

a. Binomial: Shoshonea pulvinata Evert \& Constance.

b. Full bibliographic citation: Evert, E.L., and L. Constance. 1982. Shoshonea pulvinata, a new genus and species of Umbelliferae from Wyoming. Systematic Botany 7: 471-475.

c. Type specimens: United States, Hyoming, Park Co., Absaroka Range, SW side of Rattlesnake Mtn., about 14.5 $\mathrm{km} \mathrm{W}$ of Cody, T53N R103W $536 \mathrm{SW} 1 / 4,2638 \mathrm{~m}$, exposed limestone-derived soil, talus and crevices, growing with Arenaria hookeri, Astragalus kentrophyta, Castilleja nivea, Eritrichium howardii, Oxytropis viscida, Pinus flexilis, Pseudotsuga menziesii, and Senecio canus, 6 Aug 1981, E.F. Evert 3424. Holotype: RM; isotypes: MO, NY, UC.

2. Pertinent synonyms: None.

3. Common name: Shoshonea.

4. Taxon codes: PDAPIZG010 (The Nature Conservancy); 3212, SHOPUL (U.S. Forest Service, Region 1).

5. Size of genus: Monotypic genus.

B. Family classification.

1. Family name: Apiaceae.

2. Pertinent family synonym: Umbelliferae.

3. Common names for the family: Parsley Family, Carrot Family.

C. Major plant group: Dicotyledoneae.

D. History of knowledge of taxon: Shoshonea pulvinata was first collected in 1979 on the west side of Rattlesnake Mountain, Park County, Wyoming, by Erwin Evert (Evert 1577, RM). Subsequent searching in 1980 and 1981 by Evert, Ronald Hartman, Robert Lichvar, Keith Deuholm, and others revealed additional populations in Park County. The genus and species were described by Evert and Constance (1982). The taxon is now also known to occur in the Owl Creek Mountains, Fremont County, Wyoming.

Shoshonea pulvinata was first discovered in Montana by John 
Pierce in 1984, near Lost Water Canyon in the Pryor Mountains, Carbon County. In 1985, Peter Lesica located a population in the Beartooth Mountains, also in Carbon County (Lesica et al. 1986). Lesica, working under contract for The Nature Conservancy, and Steve Shelly of the Montana Natural Heritage Program, 5earched many areas of the Pryor and Beartooth mountains unsuccessfully in 1986. During 1983, Lichvar et al. (1985) conducted a floristic study of Big Horn Canyon National Recreation Area, which includes the extreme east edge of the Pryor Mountains. They did not locate any populations of Shoshonea.

In 1987, the Montana Natural Heritage Program was contracted by the U.S. Fish and Wildlife Service to conduct a status survey of Shoshonea pulvinata in Montana (Project Agreement SE-3-P-1). In July, 1987, under subcontract, Lesica conducted additional field surveys of appropriate habitat in the Beartooth and Pryor mountains of Carbon County. In August, 1987, Lesica and Shelly were denied access to the Big Horn Mountains, on the Crow Indian Reservation in Big Horn County, by the Crow Tribal Council (Appendix A, P. 36). Although Shoshonea may be present on Crow tribal lands, no information is available for this area.

Prlor to 1987, the only two occurrences of Shoshonea pulvinata known In Montana were the Grove Creek Pinnacles (Beartooth Mountains) and Lost Water Canyon (Pryor Mountains)). The latter site could not be relocated by Lesica in 1985. During the 1987 field surveys, Lesica did relocate this site, and discovered one additional population in the Pryor Mountains (Mystery Cave). No new populations were found in the Beartooth Mountains (Figs. 1, 2, pp. $3-4$ ).

E. Comments on current alternative taxonomic treatments: There are no known current alternative taxonomic treatments.

2. Present legal or other formal status.

A. International: None

B. National.

1. United States.

a. Present designated or proposed legal protection or regulation: Currently, Shoshonea pulvinata is under notice of review for potential listing as a threatened species under the U.S. Endangered Species Act of 1973 (U.S. Department of Interior, 1985). Specifically, it is included in Category 2 (taxa for which information now in possession of the Service indicates that listing as a threatened or endangered species is possibly appropriate, but for which substantial data on biological vulnerability and threats are not currently known or on file to support listing). 
(1)
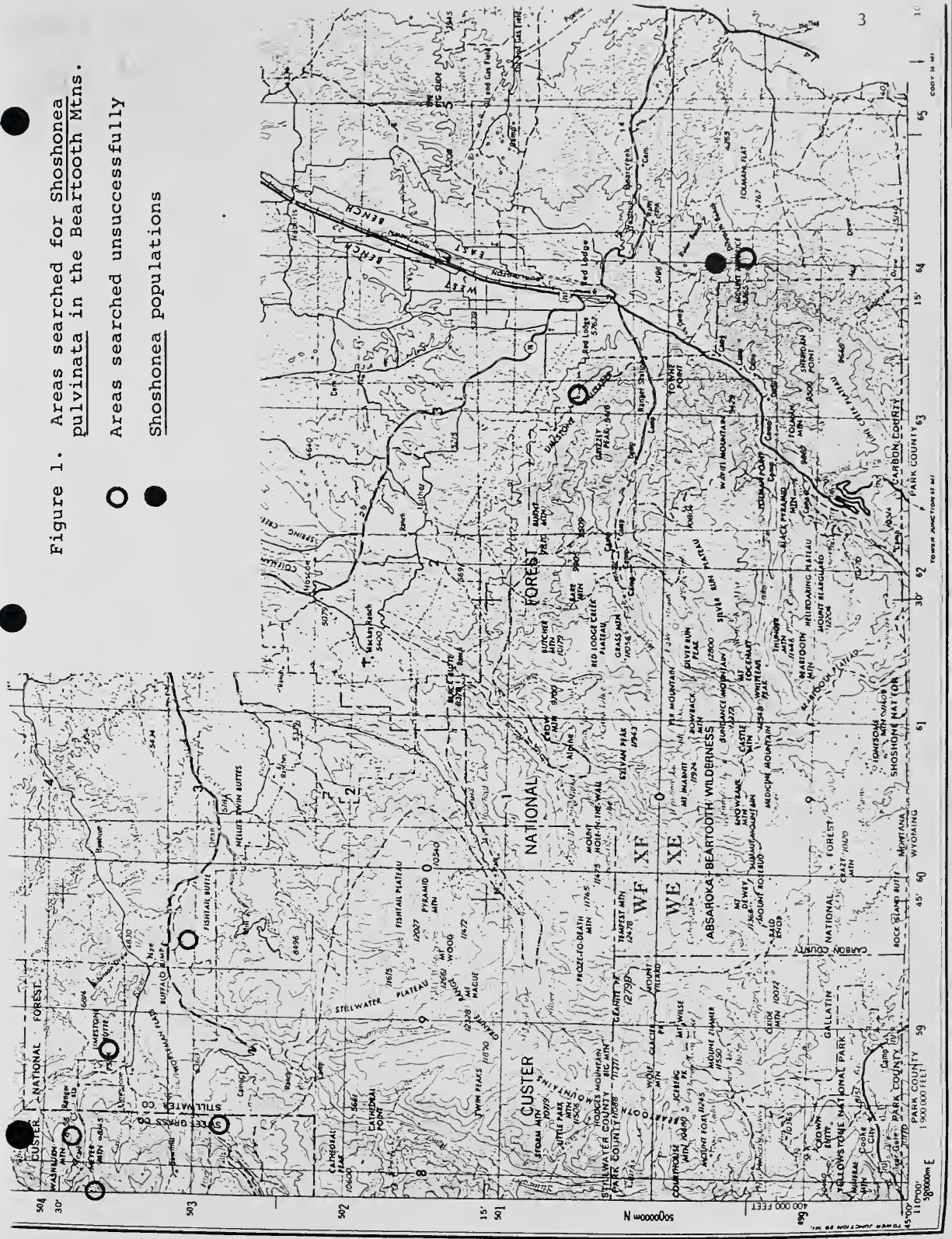
b. Other current formal status recommendations: Shoshonea pulvinata is currently 1 isted as "endangered or threatened throughout range" (global rank = G2G3) by the Wyoming Natural Heritage Program (Hollis Marriott, personal communication) and the Montana Natural Heritage Program (Shelly 1988).

c. Review of past status: No previous history of legal or formal status.

C. State.

1. Montana.

a. Present designated or proposed legal protection or regulation: None.

b. Other current formal status recommendations: Shoshonea pulvinata is currently listed as "critically endangered" in Montana (state rank $=51$ ) by the Montana Natural Heritage Program (Shelly 1988).

c. Review of past status: No past status.

2. Wyoming.

a. Present designated or proposed legal protection or regulation: None.

b. Other current formal status recommendations: Shoshonea pulvinata is currently listed as "endangered" in Wyoming (state rank $=52$ ) by the Wyoming Natural Heritage Program (Hollis Marriott, personal communication).

c. Review of past 5 tatus: No past status.

3. Description.

A. General nontechnical description: Shoshonea pulvinata is a low, mat-forming, herbaceous, long-lived perennial. The plants have a woody taproot and branching underground stems. The above-ground stems are 1-3 inches in length and usually clothed at the base with remnants of the previous year's leaf sheaths. The leaves are approximately $\emptyset .2-1.0$ inches long and $\emptyset .2-\emptyset .8$ inches wide, with a petiole approximately half the length of the leaf. The leaf blades are oddly pinnate with 5-11 divisions and oblong to oval in outline. The leaf petioles are swollen and papery at the base. The herbage is smooth to somewhat roughened. The inflorescence is a compound umbel approximately $1 / 2-3 / 4$ inch in diameter. The flowers in these umbels are small (ca. 1/8 inch in diameter) and light yellow in color. The fruits are approximately $1 / 8$ inch long, slightly roughened to the touch, and wi thout wings. 
Shoshonea forms dense cushions up to $11 / 2$ feet in diameter in open, exposed sites, but is usually smaller and more loosely branched in partially shaded, less exposed sites. Plants prabably begin blooming in May in exposed habitats, and some plants can 5 till be found in bloom in July in shaded sites.

8. Technical description: The following description is taken from Evert and Constance (1982). Plants law, acaulescent, caespitasepulvinate, scaberulous, pleasantly aromatic, herbaceous, perennial, 2-8 cm tall, from a woody taproot and branching (underground) caudices that are clothed above with the petioles from previous years. Leaves petiolate, subcoriaceaus, imparipinnate, the blades ovate or oblong in outline, $5-25 \mathrm{~mm}$ long, 3-20 $\mathrm{mm}$ wide, the 2-5 pairs of leaflets 1 inear or oblanceolate, cuspidate, 2-10 mm long, $0.5-1.5 \mathrm{~mm}$ wide, the lower leaflets frequently $2-$ or 3-lobed; petioles dilated and scarioussheathing near the base, 5-20 mm long. Inflorescence of subcompact compound umbels $\emptyset .75-1.5 \mathrm{~cm}$ wide at anthesis; peduncles erect, 2-5 cm long; involucel dimidiate, the 5-8 basally connate, entire bractlets 1 inear or lanceolate, 2-6 mm long, slightly exceeding the flowers; umbellets of $1-5$ sessile perfect flowers and 2-6 pedicillate 5 taminate flowers, the pedicels up to $4 \mathrm{~mm}$ long; flowers yellow, the sepals 5 for ocassionally 4), prominent, unequal, ovate-lanceolate, 1-1.5 mm long, the petals oblong-spatulate with a narrower inflexed apex, about $1.5 \mathrm{~mm}$ long, the stylopodium absent, the disk semicircular, the ovary densely scaberulous. Fruit sessile, scaberulous, oblong or ovoid-elliptic, subterete to slightly compressed laterally, not constricted at the commissure, 2-4 mm long, $1.5-3$ $\mathrm{mm}$ wide; ribs subequal, prominent to subprominent, obtuse, not winged, ovate in transection, up to $0.3 \mathrm{~mm}$ long, $0.3 \mathrm{~mm} w i d e$; pericarp with lignified strengthening cells; carpophore absent or vestigial, bipartite, and usually falling with the mericarps; oil tubes small, 2-6 in the intervals, 2-6 on the commissure and frequently 1 in each $r$ ib; seed dorsally compressed, the face plane to concave. Chromosome number $2 n=22$ (Evert 1772).

c. Local field characters: In open habitats, the dense cushion-like habit of Shashonea separates it from all other members of the Apiaceae with which it might co-occur. Vegetatively, Shoshonea might be confused with Astragalus kentrophyta, which is often found in similar habitats, but $A$. kentrophyta has three-parted leaflets. In more shaded habitats, Shoshonea might be confused with various species of Cymopterus, but the latter are generally more erect and have leaves which are either bipinnate or tripinnate. The leaves of Shoshonea are simply pinnate.

Thus, the mat-forming habit, small yellow umbels of flowers, and pinnate leaves distinguish Shoshonea from all other species.

D. Identifying characteristics of material which is in interstate or international commerce or trade: No interstate or international commerce or trade known. 
E. Photographs and line drawings: Figure 3 is a copy of the iljustration which accompanied the publication of Shoshonea pulvinate (Evert and Constance 1982). The color slides (p. q) are duplicates of those taken at the sites indicated. Additional slides of Shoshonea and its habitat are housed at the office of the Montana Natural Heritage Program, Melena, Montana.

4. Significance.

A. Natural: Shoshonea is a monotypic genus. Its taxonomic position indicates that it may contain a relatively large amount of unique genetic material. The species is adapted to shallow limestone soils in harsh windswept sites. It may be important in stabilizing limestone talus slopes in some instances. Obligate relationships with other species are unknown.

B. Human: The Apiaceae is a taxonomically difficult family. The discovery of this genus may help to elucidate generic relationships within the Apiaceae. Shoshonea pulvinata may have hortlcultural potential as a rock garden plant. Otherwise, the species has no known agricultural, economic or other human uses or significance.

5. Geographical distribution.

A. Geographical range: Shoshonea pulvinata is currently known in Wyoming from the Absaroka Mountains, Park County, and the Owl Creek Mountains, Fremont County, and in Montana from the Pryor Mountains and Beartooth Mountains of Carbon County.

B. Precise occurrences.

1. Populations currently known to be extant.

a. Montana: Populations are 1 isted in Table 1, p. 10; exact locations are provided in Maps 1-3, pp. 11-13.

b. Wyoming: Populations are listed in Table 2, pp. 14-16. Since all of these populations have been discovered within the last ten years, they are presumed to be extant.

2. Populations known or assumed extirpated: None.

3. Historically known populations where current status is not known: Although populations in Wyoming are all presumed to be extant, survey work has not been completed in the last several years. The current status of these populations in terms of abundance and threats is not known.

4. Locations not yet investigated believed likely to support additional natural populations.

a. Wyoming: Much of the appropriate habitat in Wyoming 

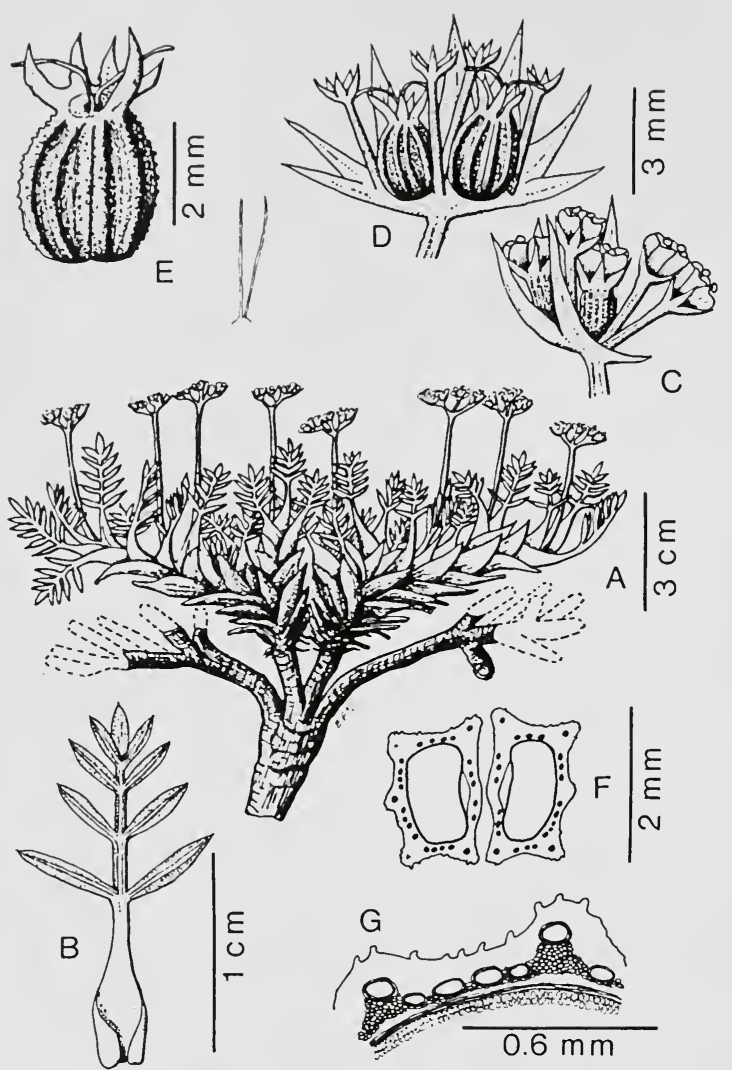

Shoshonea pulvinata. A. Habit. B. Leaf. C. Flowering umbellet. D. Fruiting umbellet. E. Mature fruit, with vestigial carpophore. F. Fruit transection. G. Pericarp transection, showing lignified cells. A-C from Evert 1918: D-G from Evert 2067.

Figure 3. Line drawing of Shoshonea pulvinata. Taken from Evert and Constance (1982). 
○

-

- 
TABLE 1. Populations currently known extant, Carbon County, Montana.

Occurrence number: $\emptyset 1$

Site name: GROVE CREEK PINNACLES (MEETEETSE SPIRES)

Latitude: 450629 Longitude: 1091339 Elevation: $7140^{\circ}$

Township \& Range: 85, 2øE Sections: 26, N/2NW/4, E'sSW/4

USGS Quad: TOLMAN FLAT

23, W'/2

Size: 7.5 minute series

Year of initial discovery: 1985

Date of most recent observation: 1986-06-24

Directions: BEARTOOTH MOUNTAINS, CA. 5 AIR MILES SSE. OF RED LODGE; HWY. 398 FROM BRIDGER TO BELFRY, THEN HWY. 397 SOUTH $4.5 \mathrm{MI}$. TO GROVE CR. RD.; WEST $5 \mathrm{MI}$. TO RANCH, GD LEFT, THEN RT. AND CROSS SOUTH FORK GRDVE CREEK.

Dccurrence number: $\emptyset \emptyset 2$

Site name: LOST WATER CANYON

Latitude: 450800 Longitude: 1082113 Elevation: $7800^{\circ}$

Township \& Range: 8S, 27E Sections: 13, SE $/ 4$

85, $28 \mathrm{Sections:} \mathrm{18,} \mathrm{W/SW/4}$

$19, N W^{\prime} / 4, N E / 4 S W / 4$

USGS Quads: EAST PRYOR MOUNTAIN, MYSTERY CAVE

Size: 7.5 minute series

Year of initial discovery: 1984

Date of most recent observation: 1987-ø7-10

Directions: PRYOR MOUNTAINS, ALONG RIDGES EAST DF LOST WATER CANYON, $\emptyset .95-1.1$ AIR MILES SW. TO SOUTH OF LITTLE ICE CAVE.

Occurrence number: $\$ 63$

Site name: MYSTERY CAVE

Latitude: 450715 Longitude: 1981901 Elevation: 7480 .

Township \& Range: 8S, $28 E$ Sections: 20, SE\%

21, SW/4

$28, N^{\prime \prime 4}$

USGS Quad: MYSTERY CAVE

Size: 7.5 minute series

Year of initial discovery: 1987

Date of most recent observation: 1987-07-13

Directions: PRYOR MDUNTAINS, ALONG RIDGES EAST OF BIG COULEE, $\emptyset .75-\emptyset .85$ AIR MILES SSE. TO WSW. OF MYSTERY CAVE. 
TABLE 2. Populations currently known extant, Wyoming.

Dccurrence number:

Site name: SHEEP MOUNTAIN

County: PARK

Latitude: 4428øळ Longitude: 1992ø2ø Elevation: 68øळ.

Township \& Range: $52 \mathrm{~N}, 184 \mathrm{~W}$ Sections: $22, \mathrm{NE}^{\prime / 4}$

USGS Quad: WAPITI

Year of initial discovery: -

Date of most recent observation: 1981-97-12

Directions: ABSAROKA RANGE; NW. CORNER OF SHEEP MT. ABOVE POST

CREEK.

Occurrence number: øळट

Site name: STAGNER MOUNTAIN

County: FREMONT

Latitude: 432720 Longitude: 1981540 Elevation: $7500^{\circ}$

Township \& Range: 6N, 5E Section: 34

USGS Quad: MORRISON CANYON

Year of initial discovery: 1982

Date of most recent observation: 1982-07-26

Directions: WIND RIVER RESERVATION, OWL CREEK MOUNTAINS, STAGNER MTN.

Occurrence number: $\$ 603$

Site name: RATTLESNAKE MOUNTAIN CREST

County: PARK

Latitude: 443330 Longitude: 1991615 Elevation: 8950.

Township \& Range: $53 \mathrm{~N}, 103 \mathrm{~W}$ Sections: $22,5 E^{1 / 4} \mathrm{TO} 17, \mathrm{NW} / 4$

USGS Quads: PAT O'HARA, CODY

Year of initial discovery: 1980

Date of most recent observation: 198ø-ø6-25

Directions: TWO MILE SEGMENT OF CREST OF RATTLESNAKE MTN., 4

MILES NORTH OF BUFFALO BILL RESERVDIR NEAR CODY.

Occurrence number: $\emptyset 04$

Site name: SW. FLANK RATTLESNAKE MOUNTAIN

County: PARK

Latitude: 443135 Longitude: 1091240 Elevation: 8650'

Township \& Range: 53N, $103 \mathrm{~W}$ Sections: 35, SW/4

36, SW/4

USGS Quad: CODY

Year of initial discovery: 1981

Date of most recent observation: 1981-98-96

Directions: SW. SIDE OF RATTLESNAKE MTN., AND NEAR SE. END, CA. 9 MI. WEST OF CODY. 
TABLE 2. (cont.).

Occurrence number: 065

Site name: LOGAN MOUNTAIN

County: PARK

Latitude: 442930 Longitude: 1091920 Elevation: 5800 .

Township \& Range: 52N, $164 \mathrm{~W}$ Section: 11, SE'/

USGS Quad: WAPITI

Year of initial discovery: 1980

Date of most recent observation: 1980-05-20

Directions: SOUTH SIDE OF LOGAN MTN., CA. 13 MI. WEST OF CODY AND $3 / 4 \mathrm{MI}$. NORTH OF U.S. HWY. 14,16 \& 20 .

Occurrence number: 906

Site name: NW. FLANK RATTLESNAKE MOUNTAIN

County: PARK

Latitude: 443635 Longitude: 1092110 Elevation: 8600'

Township \& Range: 54N, $104 \mathrm{~W}$ Section: 35, 5W/

USGS Quad: PAT O'HARA

Year of initial discovery: 1979

Date of most recent observation: 1981-06-19

Directions: NW. SIDE OF RATTLESNAKE MOUNTAIN, CA. $16 \mathrm{MI}$. NW. OF CODY.

Occurrence number: 097

Site name: HEART MOUNTAIN

County: PARK

Latitude: 443955 Longitude: 1090735 Elevation: 7800 '

Township \& Range: $54 \mathrm{~N}, 102 \mathrm{~W}$ Section: 15, NE//

USGS Quad: CODY

Year of initial discovery: -

Date of most recent observation: 1981-67-30

Directions: NEAR TOP OF WEST SUMMIT OF HEART MTN., CA. $2 \emptyset \mathrm{MI}$. NORTH OF CODY.

Occurrence number: 008

Site name: CEDAR MOUNTAIN

County: PARK

Latitude: 442940 Longitude: 1091015 Elevation: $7680^{\circ}$

Township \& Range: 52N, 1ø2W Section: 8, NW/4

USGS Quad: DEVILS TOOTH

Year of initial discovery: 1981

Date of most recent observation: 1981-ø8-63

Directions: NEAR THE TOP OF CEDAR MTN., CA. 5.5 AIR MI. WSW. OF CODY. 
Decurrence number: DO9

Site name: BALD RIDGE

County: PARK

Latitude: 444800 Longitude: 1092000 Elevation: 8000'

Township \& Range: 56N, $104 \mathrm{~W}$ Section: 25, SE

USGS Quad: .DEEP LAKE

Year of initial discovery: 1986

Date of most recent observation: 1986

Directions: BALD RIDGE, CA. 2 MI. NDRTH OF DEAD INDIAN PASS, SE. RIM OF CLARKS FORK YELLOWSTONE RIVER CANYON. 
has had recent floristic survey work. Erwin Evert has thoroughly surveyed the Absaroka Range in the drainage of the North Fork of the Shoshone River. Rob Kirkpatrick has surveyed the Absaroka Range from the North Fork of the Shoshone River south to the Owl Creek Range (M.S. Thesis, Department of Botany, University of Wyoming, Laramie). The Big Horn Mountains have been studied by B.E. Nelson and Ron Hartman (Nelson and Hartman 1984). Because of their location on the Wind River Indian Reservation (Arapaho and Shoshone tribes), the Owl Creek Mountains have not been thoroughly searched. In addition, the northeast corner of the Big Horn Mountains of Wyoming have not been surveyed as intensively as the rest of the range, and may harbor undiscovered populations (B.E. Nelson, Rocky Mountain Herbarium, University of Wyoming, personal communication).

b. Montana: There are two or three areas in the Big Horn Mountains in Big Horn County, on the Crow Indian Reservation, where Shoshonea might be expected to occur. These areas were not investigated, as the authors were denled access to the reservation by the Crow Tribal Council (Appendix A, p. 36). Also, Sheep Mountain, just south of Luther on the north side of the Beartooth Mountains (T7S RI9E Sec 6), was not surveyed. Shoshonea might be expected to occur there; however, suitable sites both east and west of Sheep Mountain were searched without success.

5. Reports having ambiguous or incomplete locality information: None known.

6. Locations known or suspected to be erroneous reports: None.

C. Biogeographical and phylogenetic history: Unknown. Shoshonea shares morphological charcteristics with many genera of North American Apiaceae, but the relationships are not clear (Evert and Constance 1982). Shoshonea pulvinata is one of several species endemic to calcareous soils in the area of the northern Big Horn Basin. Other such species include Penstemon caryi, Erigeron allocotus, and Eriogonum lagopus.

6. General environment and habitat description.

A. Concise statement of general environment and habitat: Shoshonea pulvinata is restricted to shallow, stoney, calcareous soils associated with exposed limestone outcrops, ridgetops and talus slopes. The vegetation of Shoshonea sites is sparse and dominated by low herbaceous plants, many of which are also matforming. In Montana, Shoshonea occurs at elevations ranging from $6,800-7,800$ feet. At this elevation the dominant zonal vegetation is Douglas fir (Pseudotsuga menziesii) forest. Shoshonea often occurs in windblast areas on the edges of these 
forests, or on exposed ridges surrounded by them. Other commonly associated species include limber pine (Pinus flexilis), Howard's alpine forget-me-not (Eritrichium howardii), and curly sedge (Carex rupestris).

B. Physical characteristics.

1. Climate.

a. Koppen climate classification: Type BSw, a steppe climate with a winter dry season east of the Rocky Mountains, where winter cold prevents appreciable precipitation; and type Dfb, the Canadian climate, with snowy winters and moderately warm summers (Visher, 1954).

b. Regional macroclimate: Red Lodge, at an elevation of 5,250 feet, is approximately $5 \mathrm{miles}$ nor thwest of the Beartooth Mountain site and $40 \mathrm{miles}$ west of the Pryor Mountain sites. For the thirty year period ending in 1989, mean July maximum and mean Jamuary minimum were $79.3^{\circ} \mathrm{F}$ and $11.7^{\circ} \mathrm{F}$, respectively. Mean annual preclpitation was $25 . \varnothing$ inches (U.S. Department of Commerce 1982).

c. Local microclimate: Shoshonea pulvinata generally occurs in areas which are exposed to full solar insolation, and in very windswept 5 ituations. Evapotranspiration and diurnal fluctuation in temperature is expected to be high. Snow accumulation in these areas is minimal, and sites are probably free of snow early in the spring. Although these areas appear dry, the soils beneath the stoney surface may hold moisture well into the summer.

2. Air and water quality requirements: Unknown.

3. Physiographic province: Fenneman (1931) places the range of Shoshonea pulvinata in the Middle Rocky Mountain Province. Hunt (1974) also classifies this area as part of the Middle Rocky Mountain Province, within the Rocky Mountain System.

4. Physiographic and topographic characteristics: In Montana, Shoshonea pulvinata occurs on 50 ils derived from 1 imestones and dolomites of the Madison group of formations (Perry 1962, Richards 1955). The Madison limestones lie on top of limestones of the Jefferson Formation. Although it is possible that Shoshonea occurs on soils derived from this latter formation also, it is believed to be mainly associated with the Madison formations. Perry (1962) indicates that both the Beartooth and Big Horn Mountains have been glaciated, while the Pryor Mountains have not.

In Montana, known sites occur at elevations of $6,800-7,400$ 
feet on the east 5 lopes of the Beartooth Mountains and $7,200-7,800$ feet in the Pryor Mountains. In Wyoming, Shoshonea occurs at elevations of 5,808-9,800 feet (Evert and Constance 1982, Hollis Marriott, Wyoming Natural Heritage Program, pers. comm.). The species is found in mountainous terrain in areas of sharp relief. In Montana, Shoshonea generally occurs on level or gently sloping ridgetops, or on the shoulders of ridges. It is occassionaly found on steeper slopes with a warm aspect. These habitats are very exposed to strong winds, and winter snow accumulation is assumed to be minimal.

In Montana, Shoshonea is found at the north end of the Big Horn Basin in the drainages of the Big Horn River and the Clarks Fork of the Yellowstone River.

5. Edaphic factors: Shoshonea pulvinata occurs in poorly developed soils derived from limestone and dolomite. Although analyses were not conducted, solls are probably highly calcareous. Veseth and Montagne (1980, p. 38) describe similar shallow soils derived from Madison Limestone in the Big Snowy Mountains of northcentral Montana. These soils are well drained, with moderately rapid runoff and moderate permeability. Soll cores have 4590\% limestone cobbles and pebbles, and a fine fraction high in silt. These solls are slightly sticky and plastic when wet, friable to very friable when moist, and slightly hard when dry. The high 5 tone and silt content may help retain moisture during the growing season. These higher elevation azonal soils have not been classified by the Soil Conservation Service.

6. Dependence of this taxon on natural disturbance: Shoshonea appears to be confined to areas where exposure to the wind minimizes snow accumulation, and where subsequent soil and vegetation development are thus inhibited. Without the effects of wind, soils would presumably mature, and zonal vegetation (i.e., Douglas fir forest) could develop and shade out individuals of Shoshonea.

7. Other unusual physical features: None observed.

C. Biological characteristics.

1. Vegetation physiognomy and community structure: In Montana, Shoshonea pulvinata occurs in relatively barren, fellfieldlike communities amidst dry forests of Douglas fir and limber pine. In these communities, scattered, small individuals of these tree species, as well as shrubby cinquefoil (Potentilla fruticosa) and Wyoming ninebark (Physocarpus monogynus), may also be present. Otherwise, the vegetation is dominated by herbaceous perennials, including graminoids such as spike fescue (Hesperochloa kingij) and curly sedge (Carex rupestris), and cushion- 
forming plants such as Howard's forget-me-not (Eritrichium howardij), 5 temless goldenweed (Haplopappus acaulis), Sweetwater milkvetch (Astragalus aretioides), rockmat (Petrophyton caespitosum), fragrant pussy-toes (Antennaria aromatica), and kelseya (Kelseya uniflora).

2: Regional vegetation types: For Montana, Ross and Hunter (1976) place the Pryor Mountain sites in the Douglas Fir Climax Forest Zone, and the Beartooth Mountain site in the Clayey and Shallow Clay Range Sites with bluebunch wheatgrass, columbia needlegrass, and western and thickspike wheatgrass (etc.) Zone. Kuchler (1964) places both the Pryor Mountain sites and the Beartooth Mountain site in the Douglas Fir Forest Zone. The forests which compose the zonal vegetation are best described as belonging to the Pseudotsuga menziesii/Physocarpus malvaceus habitat type, possibly intergrading into the Pinus flexilis/ Juniperus communis habitat type (Pfister et al. 1977).

3. Frequently associated specles: All of the species frequently associated with Shoshonea pulvinata in Montana are natives. These include:

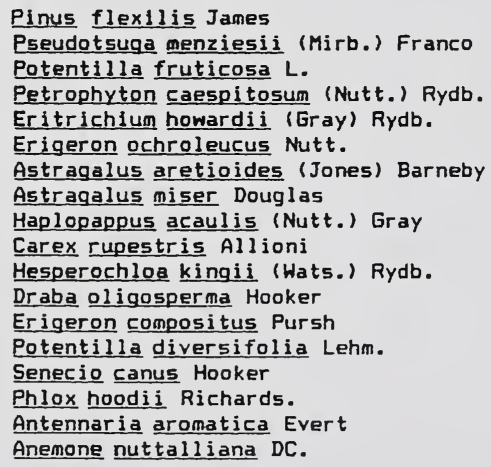

4. Dominance and frequency of the taxon: In the Pryor Mountains, Shoshonea pulvinata occurs in colonies of approximately $100-1,500$ plants, in narrow belts of habitat on the rims above canyons. Although canopy cover of this species rarely exceeds $5-10 \%$, total vegetation cover is low, and Shoshonea is often one of the dominant herbaceous species. In the Beartooth Mountains, Shoshonea occurs on relatively broad ridgetops, in colonies of $1, \varnothing \varnothing \emptyset-5, \varnothing 0 \emptyset$ plants. Again, although its canopy cover is usually less than $16 \%$, it can be one of the dominant herbaceous species, as it is on the ridge north of the North Fork of Grove Creek. 
5. Successional phenomena: Although Shoshonea pulvinata sometimes occurs in partial shade at the edges of forests, plants found in these areas appear to be less vigorous than those in full light. The vast majority of plants at any one site are found in open areas. These observations indicate that Shoshonea prefers full or nearly full sunlight. Forest encroachment of Shoshonea habitat would cause increased snow cover, slower warming in spring, and lower light

intensities, which could, in turn, cause extirpation of the species. Sites where Shoshonea pulvinata occurs are on ridgetops, and on the rims above the windward side of deep canyons. These sites are apparently maintained in an early successional stage by their extreme exposure to wind.

b. Dependence on dynamic aspects of biotic associations and ecosystem features: Unknown.

7. Other endangered, threatened, rare, or vulnerable species occurring in habitat of this taxon: The following species have a limited distribution in Montana, but are more widespread elsewhere.

Astragalus aretioides (Jones) Barneby - listed as rare by Lesica et al. (1984); listed as "state endangered" (S2) by the Montana Natural Heritage Program (Shelly 1988).

Hymenoxys torreyana (Nutt.) Parker - listed as rare by Lesica et al. (1984); listed as "state endangered" (S2) by the Montana Natural Heritage Program (Shelly 1988).

Townsendia spathulata Nutt. - listed as "state endangered" (S2) by the Montana Natural Heritage Program (Shelly 1988).

Physocarpus monogynus (Torr.) Coult. - listed as rare by Lesica et al. (1984); listed as "state status unknown, possibly threatened or endangered" (SU) by the Montana Natural Heritage Program (Shelly 1988).

7. Population biology of the taxon.

A. General summary: Known populations of Shoshonea pulvinata in Montana consist of three or four subpopulations separated by less than $1 / 2$ mile. Subpopulations consist of $10 \emptyset-1,500$ plants in the Pryor Mountains, and 1, $100-5, \varnothing 00$ plants in the Beartooth Mountains. Small, non-reproductive plants were present at all sites, indicating that successful recruitment is occurring. Areas of seemingly appropriate habitat were observed to be unoccupied by Shoshonea, which may indicate that the species is not completely competent at colonizing new sites. The breeding system of Shoshonea is unknown. On several occasions, flies in the Family Syrphidae were observed on the flowers. 
B. Demography.

1. Known populations: There are three known populations of Shoshonea pulvinata in Montana, one in the Beartooth Mountains and two in the Pryor Mountains. There are currently eight known populations in Wyoming. In Montana, population size ranges from 1,500 to 6,000 plants. Detailed demographic information is generally unknown for the Wyoming populations, but in one case (Rattlesnake Mountain Crest (פ93)) the species was described as "abundant."

2. General demographic details (Montana):

a. Grove Creek Pinnacles.

1. Area occupied by population: ca. 70 acres in three subpopulations.

2. Estimated number of individuals: ca. 6,900 plants.

3. Density: Scattered, ca. 1-2 plants/sq. yd.

4. Presence of dispersed seeds: Unknown.

5. Evidence of reproduction: Small, nonreproductive individuals observed, and presumed to be juveniles. No seedlings observed.

6. Evidence of population expansion or decline: None, but possibly stable or increasing.

b. Lost Water Canyon.

1. Area occupied by population: ca. 25 acres in four subpopulations.

2. Estimated number of Individuals: ca. 3,øøळ plants.

3. Density: Unknown.

4. Presence of dispersed seeds: Unknown.

5. Evidence of reproduction: Small, nonreproductive individuals observed, and presumed to be juveniles. No seedlings observed.

6. Evidence of population expansion or decline: None, but possibly stable or increasing.

c. Mystery Cave.

1. Area occupied by population: ca. 15 acres in three subpopulations.

2. Estimated number of individuals: ca. 1,500 plants.

3. Density: Unknown.

4. Presence of dispersed seeds: Unknown.

5. Evidence of reproduction: Small, nonreproductive individuals observed, and presumed to be juyeniles. No seedlings observed.

6. Evidence of population expansion or decline: None, but possibly stable or increasing. 
C. Phenology.

1. Patterns: The first observations in Montana have been made in mid-June in the Beartooth Mountains. At this time, some of the Shoshonea plants were in flower, but most were already in fruit. In the Pryor Mountains in early July, most of the plants were in fruit, with seed dispersing, but a few plants growing in partial shade were still in flower. It is presumed that flowering on these exposed sites begins in May, and probably peaks during the latter part of that month or in early June. Fruit matures during June and early July, and dispersal probably begins in late June and continues through July and into early August. It is not known when Shoshonea becomes senescent, although it is suspected that the plants may be winter green, at least in part. The time of seed germination is unknown.

Due to its unusual growth form and leaf morphology, Shoshonea pulvinata can be recognized in the field throughout the growing season.

2. Relation to climate and microclimate: Details are unknown.

D. Reproductive ecology.

1. Types of reproduction: Details of the breeding system are unknown. Reproduction appears to be entirely by seed; no evidence of asexual reproduction was observed.

2. Pollination.

a. Mechanisms: Probably by insects. Faegri and van der $\mathrm{Pijl}$ (1971) state that members of the Apiaceae are adapted to pollination by a wide range of insects, including beetles, flies, and bees.

b. Specific known pollinators: In several instances, flies of the Family Syrphidae were observed on the flowers of Shostionea. Dtherwise, specific pollinators are unknown.

c. Other suspected pollinators: None known.

d. Vulnerability of pollinators: Unknown.

3. Seed dispersal.

a. General mechanisms: Shoshonea pulvinata does not appear to have any specialized mechanisms for longdistance dispersal. Although not directly observed, it is presumed that the mericarps fall from the inflorescence in the vicinity of the parent plant. Dispersal away from the parent plant may involve movement by wind, or by animal vectors such as ants or 
rodents. The mericarps do have oil tubes (Evert and Constance 1982), and the oil in the fruit may serve as an attractant to animal dispersers (van der Pijl 1982).

b. Specific agents: None known.

c. Vulnerability of dispersal agents and mechanisms: Unknown.

d. Patterns of propagule dispersal: Unknown.

4. Seed biology.

a. Amount and variation of seed production: Details are unknown. Most plants that were observed produced some fruit, and most inflorescences examined had at least one maturing fruit.

b. Seed viability and longevity: Unknown.

c. Dormancy requirements: Unknown.

d. Germination requirements: Unknown.

e. Percent germination: Unknown.

5. Seedling ecology: Details are unknown. Many species of windswept alpine fellfields require the ameliorated microclimate, and accumulations of organic matter, provided by "nurse plants" (Griggs 1956). Shoshonea pulvinata may have similar requirements.

6. Survival and mortality: Details are unknown. Shoshonea will tolerate only partial shading, and occurs mainly in relatively open plant communities. These factors suggest that it is a stress tolerator species sensu Grime (1979), and is thus probably a poor competitor.

7. Overall assessment of taxon's reproductive success: The presence of small non-reproductive plants, which are presumed to be juveniles, in all of the Montana Shoshonea pulvinata populations indicates that the species is reproducing successfully. The fact that no seedlings were observed during the 1986 and 1987 field seasons may be a result of the general drought conditions which have prevailed during that time. Judging from the large size of many of the plants, Shoshonea is a long-lived perennial. The relatively long life of individual plants probably compensates for sporadic seedling recruitment. There is unoccupied, apparently suitable habitat in both the Pryor and Beartooth mountains in Montana, perhaps indicating that Shoshonea does not readily establish new populations. Nevertheless, it appears that established populations are stable at this time. 
8. Population ecology of the taxon.

A. General summary: Shoshonea pulvinata occurs in sparse vegetation of open or occasionally partially shaded fellfieldlike habitats. The species is probably intolerant of intense competition and full shade. In the Pryor Mountains in Montana, subpopulations occur in narrow belts along the windward rims of canyons. In the Beartooth Mountains, subpopulations occupy larger, windswept ridgetop areas. Although large grazing animals such as wild horses or mountain sheep may preferentially use these communities during the winter when they are more free of snow cover than adjacent areas, no evidence of grazing damage was observed.

B. Positive and neutral interactions: None known. Most species of herbaceous vascular plants have mycorrhizal associations with fungi in the Family Endogonaceae (Gerdemann 1968).

C. Negative interactions.

1. Herbivores, predators, pests parasites and diseases: None known. At the Grove Creek Pinnacles 5 ite in the Beartooth Mountains, at least two species of swallowtail butterflies (Family Papilionidae) were observed. Larvae of many butterflies in this family are specialized feeders on plants in the Apiaceae; however, no herbivore damage to Shoshonea plants was observed during the surveys.

2. Competition.

a. Intraspecific: In most cases, Shoshonea pulvinata plants are widely spaced. Although above-ground interference is probably not important, competition for nutrients and water may be occurring.

b. Interspecific: Shoshonea occurs only in areas with relatively sparse vegetation cover and appears to be intolerant to shading, indicating that it is probably a poor competitor. Based on its growth form and habitat preferences, Shoshonea would probably be considered a stress tolerator, sensu Grime (1982). These species are generally poor competitors. The observations indicate that the shade and litter created by a forest overstory may also have a negative effect on Shoshonea plants.

3. Hybridization.

1. Naturally occurring: None known.

2. Artificially induced: None known.

3. Potential in cultivation: Unknown. 
E. Other factors of population ecology: None known.

9. Current land ownership and management responsibility.

A. General nature of ownership: United States Government and private.

B. Specific landowners (Montana):

1. USDA Forest Service

Custer National Forest

P.D. Bax 2556

Billings, MT 59163

2. USDI Bureau of Land Management

Billings Resource Area Headquarters

P.0. Box 2 $2 \emptyset$

Billings, MT 59101

3. USDI National Park Service

Big Horn Canyon National Recreation Area

P.O. Box 458

Fort Smith, MT 59935

4. Towe Farms Inc.

191 N. Frontage Rd.

Deer Lodge, MT 59722

5. Retna Life \& Casualty

Aetna Realty Investors, Inc.

YF 93, City Place

Hartford, CT $\$ 6156$

C. Management responsibility: Same as ownership given above, except for Towe Farms land, which is managed by Waynard and Wylie Anderson, Belfry, MT.

D. Easements, conservation restrictions, etc.: A portion of the Lost Water Canyon site in the Pryor Mountains is in a parcel proposed for designation as a research natural area by the U.S. Forest Service. The Mystery Cave site is on the Pryor Mountain Wild Horse Range, and one of the subpopulations is in Big Horn Canyon National Recreation Area.

A private holding on the Grove Creek Pinnacles site in the Beartooth Mountains is owned by Aetna Life \& Casualty (T8S, R2øE, Section 23, NW/4NW/4, S/2NW/4, SW/4, SW/4SE/4). Negotiations for potential transfer of this parcel to the Montana/Wyoming Field Office of The Nature Conservancy are in progress $1 \mathrm{~J}$. Bird, The Nature Conservancy, pers. comm.).

10. Management practices and experience.

A. Habitat management. 
1. Review of past management and 1 and use experiences.

a. Shoshonea pulvinata: At the Grove Creek Pinnacles site In the Beartooth Mountains, the surrounding land has been used for livestock grazing; however, the actual sites have recelved little or no grazing pressure. There are also mining claim markers on the site, but no mining activity has taken place. In the Pryor Mountains, the Lost Water Canyon site is on a livestock grazing allotment, and the Mystery Cave site is on the Pryor Mountain Wild Horse Range. However, field observations indicate that grazing has had little impact on the Shoshonea populations.

b. Related taxa: None known.

c. Other ecologically similar taxa: Not reviewed.

2. Performance under changed conditions: Not applicable.

3. Current management policies and actions: Current management is the same as outlined under past management. To our knowledge the federal agencies have no intention of changing current management schemes. It is not known how the proposed designation of the Lost Water Canyon area as a research natural area will affect managenent. The Towe Farns owners have expressed an interest in subdividing some of their land for residential development (J. Bird, The Nature Conservancy, personal communication).

4. Future land use: Present public land uses will probably continue. In addition, mining activity and residential development of private land may potentially occur in some areas.

B. Cultivation.

1. Controlled propagation techniques: None known.

2. Ease of transplanting: Not known.

3. Pertinent horticultural knowledge: Not reviewed.

4. Status and location of presently cultivated material: None known.

11. Evidence of threats to survival.

A. Present or threatened destruction, modification, or curtailment of habitat or range: Shoshonea pulvinata occupies habitats which are little threatened by human activities. Timber harvesting in adjacent forest communities could adversely affect Shoshonea sites, but the timber in most adjacent areas has a low commercial value. The presence of mining claim markers at the 
Grove Creek Pinnacles site indicates that mining activity is a possibility, but the potential appears to be low.

8. Overutilization for commercial, sporting, scientific, or educational purposes: No threats known.

C. Disease, predation, or grazing: At the present time, populations of Shoshonea pulvinata do not appear to be threatened by livestock grazing. The sites are probably free of snow earlier in the year than surrounding areas, and may be favored by grazing animals in early spring. If grazing pressure from wild horses were to increase, Shoshonea populations might be adversely affected. In the Rocky Mountains, bighorn sheep use habitats similar to Shoshonea sites as winter range. If bighorn sheep were reintroduced in large numbers in the Pryor or Beartooth mountains, they might pose a threat to Shoshonea populations.

D. Inadequacy of existing regulatory mechanisms: None known.

E. Other natural or man-made factors: None known.

\section{I1. ASSESSMENT AND RECOMENDATIONS}

12. General assessment of vigor, trends, and status: In Montana, Shoshonea pulvinata is presently known from three sites in Carbon County. An estimated 10,500-12,500 plants occur at these three $5 i$ tes. Based on limited observations, Shoshonea populations appear to be stable. Currently there are no serious threats to these populations. The status of populations in Wyoming is currently unknown.

13. Recommendations for listing or status change.

A. Recomendation to U.5. Fish and Wildlife Service: On the basis of current information summarized in this status report, it is recommended that Shoshonea pulvinata be retained in Category 2. Although there are no apparent threats to populations of Shoshonea pulvinata in Montana, the species has few populations and a very localized distribution. The complete distribution, abundance, and condition of Shoshonea populations in Wyoming, which contains the main range of the species, are presently unknown. Final status recommendations should be made upon completion of survey work in Wyoming.

B. Recommendations to other U.S. federal agencies: Shoshonea pulvinata has been placed on lists of sensitive plant species for Region One of the U.S. Forest Service, and for the Montana State Office of the U.S.D.I. Bureau of Land Management. Personnel charged with management of lands supporting populations of Shoshonea should be made aware of its presence and locations. The impacts of any change in management practices (i.e., timber harvesting, mining, increased stocking rates) on Shoshonea populations should be assessed before belng implemented. 
C. Other status recommendations.

1. Counties and local areas: No recommendations.

2. States: Shoshonea pulvinata is currently listed as $\mathrm{S} 1$ ("critically state endangered") in Montana, by the Montana Natural Heritage Program (Shelly 1988). No change in status is recommended.

3. Dther nations: Not pertinent.

4. International: No recommendations.

14. Recommended critical habitat: Because the status of Shoshonea pulvinata has not been determined for the part of its range in Hyoming, critical habitat is not being recommended at this time.

15. Conservation/recovery recommendations.

A. General conservation recommendations.

1. Recommendations regarding present or anticipated activities: The effects of mining, logging, and increased grazing pressure in areas supporting Shoshonea populations should be assessed before any of these activities are implemented.

2. Areas recommended for protection: The Grove Creek Pinnacles site in the Beartooth Mounatins contains the largest known population of Shoshonea in Montana, and was nominated as a potential natural area at the 1986 Montana Natural Areas Conference (Peterson et al. 1987). The Lost Water Canyon area has been proposed for designation a U.S. Forest Service research natural area (Habeck 1988). The lands supporting Shoshonea populations should be included in the proposed reserves.

3. Habitat management recommendations: No recommendations are being made at this time.

4. Publicity sensitivity: Low.

5. Other recommendations: None.

B. Monitoring activities and research needs: Demographic monitoring studies (Lesica 1987, Palmer 1987) should be initiiated at one subpopulation at the Grove Creek Pinnacles site in the Beartooth Mountains, and for one subpopulation in the Pryor Mountains. Data from these transects can be used to assess and predict the performance of Shoshonea populations (Menges 1986). Future management recommendations can then be made based on a more thorough knowledge of the population biology of Shoshonea pulvinata. Detailed field surveys are needeed in Wyoming, to further assess the known populations and any threats to them, and to locate any additional new sites. Field surveys on the 
Shoshone National Forest are planned in 1988 (Hollis Marriott, Wyoming Natural Heritage Program, pers. comm.).

16. Interested parties:

Office of Endangered Species

ATTN: Dr. James Miller

U.S. Fish and Wildlife Service

Region 6

P.Q. Box 25486

Denver Federal Center

Denver, CD 80225

Endangered Species Field Dffice

ATTN: Carol Taylor

U.S. Fish and Wildlife Service

Federal Building, 301 5. Park

P.O. Box 10023

Helena, MT 59626

Dffice of Endangered Species

ATTN: Dr. John Fay

U.S. Fish and Wildlife Service

Washington D.C. 20240

U.S. Forest Service, Region One

ATTN: Angela Evenden

Federal Building

P.O. Box 7669

Missoula, MT 59867

The Nature Conservancy

ATTN: Dr. Larry Morse

1800 N. Kent Street

Arlington, VA 22299

Rocky Mountain Heritage Task Force

ATTN: Dr. Ben Brown

The Nature Conservancy

134 Union Blvd., Suite 125

Lakewood, CD 8ø228

The Nature Conservancy

ATTN: Dr. Joan Bird

Montana/Wyoming Field Office

P.0. Box 258

Helena, MT 59624

Holl is Marriott

Wyoming Natural Heritage Program

3165 University Station

Laramie, WY 82071 


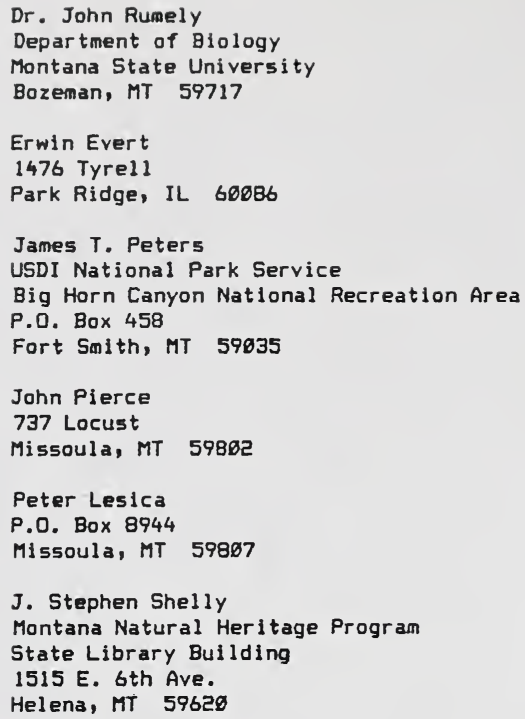

III. INFORMATION SOURCES

17. Sources of Information.

A. Publications.

1. References cited in report: see Literature Cited (pp. 3435).

2. Other publications/sources: None known.

B. Museum collections: Specimens from all known Montana populations are deposited at the University of Montana Herbarium in Missoula (MONTU). Duplicates are deposited at CA, NY, and RM. Specimens from all known Wyoming populations are deposited at the Rocky Mountain Herbarium (RM), University of Wyoming, Laramie. Specimens from MONTU and RM were examined in this study. The following list of known herbarium specimens is organized by occurrence number, for Montana and Wyoming:

$$
\begin{aligned}
& \text { Montana: } \emptyset \varpi 1 \text { - P. Lesica (3417), MONTU } \\
& \text { J.S. Shelly (1162), MONTU } \\
& \text { øø2 - P. Lesica (4386, 4388, 4389), MONTU }
\end{aligned}
$$


603 - P. Lesica (4391, 4394), MONTU

Wyoming: 001 - E.F. Evert (1772), RM; (2113), RM, UC; (3118), RM

$\emptyset 92$ - R.W. Lichvar (5382), RM

963 - D.L. Martin (1432), RM

994 - E.F. Evert (3424), RM

R.L. Hartman et al. (13924), RM

995 - E.F. Evert (1761), RM; (1946), RM, UC; 2967, UC; (3279), RM, UC

906 - E.F. Evert (1577), RM; (1918), RM, UC; (2778), RM

907 - E.F. Evert (3334), RM

R.L. Hartman (13500), RM

988 - E.F. Evert (3394), RM

R.L. Hartman \& K. Deuho Im (11418), RM

R.L. Hartman et al. (11431), RM, UC

009 - B.E. Nelson (12506), RM

C. Fieldwork.

1. Surveys by the authors:

17-19 June 1985 (Lesica)

24-26 June 1986 (Shelly, Lesica)

8-13 July 1987 (Lesica)

Surveys were conducted in the Beartooth and Pryor mountains, Carbon and Stillwater counties; Natural Heritage field forms, photographs, and herbarium vouchers.

D. Knowledgeable individuals:
John Pierce
737 Locust
Missoula, MT 59802

E. Other information sources: Color slides and field forms are on file at the office of the Montana Natural Heritage Program, and the Montana/Wyoming Field Office of The Nature Conservancy (see section II.16. for addresses).

18. Summary of materials on file: All detailed field forms, maps and color slides are on file at the office of the Montana Natural Heritage Program. Herbarium vouchers for Montana populations are deposited at the University of Montana Herbarium (MONTU). 
IV. AUTHORSHIP

19. Initial authorship:

Peter Lesica

P.O. Box 8944

Missoula, MT 59807

J. Stephen Shelly

Montana Natural Heritage Program

State Library Building

1515 E. 6th Avenue

Helena, MT 59620

Phone: $406-444-3099$

20. Maintanance of status report: The Montana Natural Heritage Program will maintain current information and update the status report as needed. Should the taxon be 1 isted as an endangered or threatened species by the U.S. Fish and Wildlife Service, the Service, through its Office of Endangered Species (Region 6), should maintain the primary file of information, encourage others to provide new information, and distribute new findings, as received, to the interested parties (section II.16.).

V. NEW INFORMATION

21. Record of revisions: Not currently applicable. 


\section{Literature Cited}

Evert, E.F., and L. Constance. 1982. Shoshonea pulvinata, a new genus and species of Umbelliferae from Hyoming. Systematic Botany 7: 471-475.

Faegri, K., and L. van der Pijl. 1971. The principles of pollination ecology. Pergamon, Oxford. $291 \mathrm{pp}$.

Fenneman, N.M. 1931. Physiography of the western United States. McGrawHill, New York. 534 pp.

Gerdemann, J.W. 1968. Vesicular-arbuscular mycorrhizae and plant growth. Annual Review of Phytopathology 6: 397-418.

Griggs, R.F. 1956. Competition and succession on a Rocky Mountain fellfield. Ecology 37: 8-20.

Grime, J.P. 1979. Plant strategies and vegetation processes. John Wiley and Sons, New York. 2ट2 pp.

Habeck, J.R. 1988. Research Natural Areas in the Northern Region: A guidebook for sclentists and educators. U.S. Forest Service, Intermountain Research Station. Missoula, Montana. Review draft.

Hunt, C.B. 1974. Natural regions of the United States and Canada. W.H. Freeman Co., San Francisco. 725 pp.

Kuchler, A.W. 1964. Potential natural vegetation of the conterminous United States. American Geographical Society, New York. 116 pp., map.

Lesica, P. 1987. A technique for monitoring nonrhizomatous perennial plant species in permanent belt transects. Natural Areas Journal 7: 65-68.

Lesica, P., G. Moore, K.M. Peterson, and J.H. Rumely. 1984. Vascular plants of limited distribution in Montana. Monograph No. 2 , Montana Acadeny of Sciences, Supplement to the Proceedings, Vol. $43.61 \mathrm{pp}$.

Lesica, P., K. Lackschewitz, J. Pierce, S. Gregory, and M. D’Brien. 1986. Noteworthy collections - Montana. Madrono 33: 31ø-312.

Lichvar, R.W., E.I. Collins, and D.H. Knight. 1985. Checklist of vascular plants for the Big Horn Canyon National Recreation Area, Wyoming and Montana. Great Basin Natural ist 45: 734-746.

Menges, E.S. 1986. Predicting the future of rare plant populations: demographic monitoring and modeling. Natural Areas Journal 6: 13-25.

Nelson, B.E., and R.L. Hartman. 1984. Flora of the Big Horn Mountains, checklist. University of Wyoming, Rocky Mountain Herbarium, Laramie. Unpublished report.

Palmer, M.E. 1987. A critical look at rare plant monitoring in the United States. Biological Conservation 39: 113-127. 
Perry, E.S. 1962. Montana in the geologic past. Montana Bureau of Mines and Geology, Bulletin 26. Montana College of Mineral Science and Technology, Butte. $78 \mathrm{pp}$.

Peterson, K.M., P. Lesica, and J.S. Shelly. 1987. Rare plants: summary report. In: Proceedings of the 1986 Montana Natural Areas Conference. The Nature Eonservancy, Helena, Montana. pp. 97-113.

Pfister, R.D., B.L. Kovalchik, S.F. Arno, and R.C. Presby. 1977. Forest habitat types of Montana. USDA Forest Service General Technical Report INT-34, Ogden, Utah. 174 pp.

Richards, P.W. 1955. Geology of the Bighorn Canyon-Hardin area, Montana and Wyoming. USDI Geological Survey Bulletin 1926, Washington D.C. 93 pp., maps.

Ros5, R.L., and H.E. Hunter. 1976. Climax vegetation of Montana based on soils and climate. USDA Soll Conservation Service, Bozeman, Montana. 64 pp.

Shelly, J.S. 1988. Plant species of special concern. Montana Natural Heritage Program, Helena. 12 pp., mimeo.

U.S. Department of Commerce. 1982. Monthly normals of temperature, precipitation, and heating and cooling degree days, 1951-1980, Montana. National Dceanic and Atmospheric Administration, Climatography of the United States No. 81 . $23 \mathrm{pp}$.

U.S. Department of Interior, Fish and Wildlife Service. 1985. Endangered and threatened wildlife and plants: review of plant taxa for listing as endangered or threatened species. Federal Register 50 (188): 39526-39584.

van der Pijl, L. 1982. Principles of dispersal in higher plants. SpringerVerlag, New York. 215 pp.

Veseth, R., and C. Montagne. 198ø. Geologic parent materials of Montana 50ils. Montana Agricultural Experiment Station Bulletin 721, Bozeman. pp. 
APPENDIX A: Letter from Crow Tribal Council. 


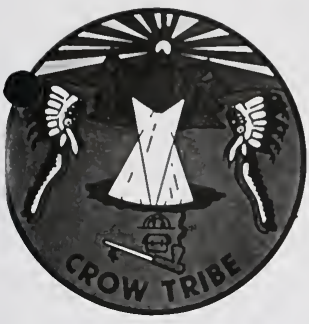

Crow Country

\section{CROW TRIBAL COUNCIL}

P.O. Box 159

Crow Agency, MT 59022
RICHARD REAL BIRD, Chairman JEROME HUGS, Vice Chairman TRUMAN C. JEFFERSON, Secretary CARLTON NOMEE, SR., Vice Secretery

August 26, 1987

Mr. J. Stephen Shelly

Botanist

Montana Natural Heritage Program

State of Montana

Montana State Library Building

1515 East 6th Avenue

Helena, Montana 59620

Dear Mr. She1ly:

In response to your letter dated, August 18, 1987, please be advised that a Crow Tribal Botanist will conduct all future plant surveys within the exterior boundaries of the Crow Reservation.

In the event that rare plant species, such as the Shoshonea Pulvinata are located, we will be pleased to inform you of the occurance.

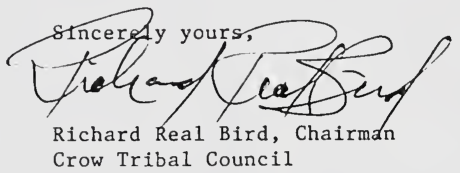

$R R B: m j h$

cc: President, Little Big Horn College Botany Department 
APPENDIX B: Element occurrence print-outs: Montana. 


\section{ELEMENT OCCURRENCE RECORD}

EOCODE : PDAPIZGळ10.Ø01

NAME: SHOSHONEA PULUINATA

COMNAME: SHOSHONEA

MARGNUM: 2 TENTEN: 2,2 IDENT: Y EORANK: A

EORANKCOMM: THREE LARGE, UNDISTURBED SUBPOPULATIONS.

SURVEYDATE: 1986-Ø6-24 LASTOBS: 1986-06-24 FIRSTOBS: 1985 GRANK: G2G3

SRANK: 51 STATE: MT COUNTYNAME: MTCAR8

QUADCODE: 4510912

QUADNAME: TOLMAN FLAT PRECISION: SC

LAT: 450629 LONG: 1991339 S: 450541 N: 450797 E: 1091324 W: 1691485

TOWNRANGE: $\$ 885 \emptyset 2 \emptyset E$ SECTION: 26 MERIDIAN: PR

TRSCOMM: N2NW4,E2SW4;23W2 PHYSPROV: MR WATERSHED: 19076066

DIRECTIONS: CA. 5 AIR MILES SSE. OF RED LODGE; HHY. 3øB FROM BRIDGER TO

BELFRY, THEN HWY. $3975.4 .5 \mathrm{MI}$. TO GROVE CR. RD. 3 WEST 5

MI. TO RANCH, THEN LEFT, RT. AND ACROSS S. FORK GROVE CREEK.

GENDESC: GRAVELIY LIMESTONE SOILS ON WINDBLOWN RIDGETOPS, AMONGST

SCATTERED PINUS FLEXILIS \& PSEUDOTSUGA MENZIESII; WITH

ERITRICHIUM HOWARDII, CYMOPTERUS HENDERSONII, KELSEYA.

ELEV: $\quad 7140$ SIZE: $\quad 50$

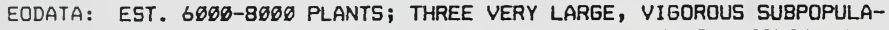

TIONS, WITH THE ELEMENT AS THE DOMINANT GROUND SPECIES IN MANY PLACES; SITES ARE ALMOST COMPLETELY UNDISTURBED, WITH ND HEEDS; EST. $3900-4000$ PLANTS IN SOUTH SUBPOPULATION.

COMMENTS: RECENTLY DESCRIBED GENUS AND SPECIES (SYST. BOT. (1982) 7 :

471); LESICA, P. (3417), 1985, SPECIMEN \#102363 MONTU.

MACODE 1: PRIVATEOWNMTUS CONTAINED1: N MACODEC: FBLRABILLIMTUS CONTAINED2: $N$

MACODE3: FBLDOMILEIMTUS CONTAINED3: N ADLMAS: $N$ MORELAN:

MOREMGMT: $\mathbf{B}$ SITECODE:

SITENAME: GROVE CREEK PINNACLES (MEETEETSE SPIRES)

OWNER: AETNA LIFE \& CASUALTY

OWNERCOMM: AETNA REALTY INYESTORS, YF 93, CITY PLACE, HARTFORD, CT.

PROTCOMM:

MGMTCOMM:

MONITOR:

MONITORNUM:

BESTSOURCE: SHELLY, J.S. 1986. FIELD SURVEYS IN CARBON COUNTY OF 23-27

JUNE; WITH P. LESICA.

SOURCECODE: F86SHEO4MTUS PNDSHEØIMTUS PNDLESøIMTUS SBSLESUMMTUS AB2

EVEのIMTUS U85LESפ2MTUS S86SHEUMMTUS

DATASENS: $N$ BOUNDARIES: $Y$ PHOTOS: $Y$ OWNERINFO: $N$

TRANSCRIBR: 86- $11-23$ J5S CDREV: $Y$ MAPPER: 86- 01-31 J55 QC: $Y$

UPDATE : 88- $94-26$ J55 
ELEMENT OCCURRENCE RECORD

EOCODE: PDAPI2GØ1ø.Øø2

NAME : SHOSHONEA.PULVINATA

COMNAME: SHOSHONEA

MARGNUM: 9 TENTEN: 2,10 IDENT: $Y$ EORANK: AB

EORANKCOMM: EXCELLENT CONDITION HABITAT; SOME POPULATIONS FAIRLY SMALL.

SURVEYDATE: 1987- 07-10 LASTOBS: 1987- $97-10$ FIRSTOBS: 1984 GRANK: G2G3

SRANK: 51 STATE: MT COUNTYNAME: MTCARB

QUADCODE : 45108234510813

QUADNAME: EAST PRYOR MOUNTAIN, MYSTERY CAVE PRECISION: SC

LAT: $4568 \varnothing \varnothing$ LONG: 1982113 S: 456721 N: 459811 E: 1982935 W: 1982123 TOWNRANGE: $\square 68$ Sø27E SECTION: 13 MERIDIAN: PR

TRSCOMM: 5E4,24NE4;TBSR28E:+ PHYSPROV: MR WATERSHED: 1øø8øø1Ø

DIRECTIONS: ALSO 18W2SW4,19NW4,NE4SW4. PRYOR MOUNTAINS, ALONG RIDGES

EAST OF LOST WATER CANYON, $\emptyset .95-1.1$ AIR MILES SW. TO SOUTH OF LITTLE ICE CAVE.

GENDESC: ON EDGES OR IN OPENINGS OF PINUS FLEXILIS-PSEUDOTSUGA

MENZIESII FORESTS; WEST-FACING RIMS ABOVE CANYONS, IN STONEY

LIMESTONE SOILS; WITH ASTRAGALUS ARETIOIDES (CONTINUED).

ELEV: $780 \varnothing$ SIZE: 25

EODATA: CA. 2900 PLANTS, IN 4 SUBPOPULATIONS (WEST-1500; NORTHEAST800; CENTRAL-100; SOUTH-50ळ); AREA IS LITTLE DISTURBED, AND PARTIALLY IN WILD HORSE RANGE; GENDESC (CONT.): ERITRICHIUM HOWARDII, HESPEROCHLOA KINGII, HAPLOPAPPUS ACAULIS.

COMMENTS: VDUCHERS-LESICA, P. (4386, 4388, 4389), 1987, MONTU;

PIERCE, J., 1984, MONTU.

MACODE 1: FFSRPLOSTIMTUS CONTAINED1: N MACODER: FBLHRPRYOIMTUS CONTAINEDE: $N$

MACODE3: FFSNFCUSTIMTUS CONTAINED3: $Y$ ADLMAS: $N$ MORELAN: MOREPROT:

MOREMGMT : B SITECODE :

SITENAME: LOST WATER CANYON

OWNER: CUSTER NATIONAL FOREST

OWNERCOMM:

PROTCOMM: PORTION OF SITE IS ON BOUNDARY DF A PROPOSED RNA.

MGMTCOMM:

MONITOR:

MONITORNUM:

BESTSOURCE: LESICA, P. 1987. FIELD SURVEYS IN CARBON COUNTY OF 8-13

JULY.

SOURCECODE: FB7LESø1MTUS PNDLESøIMTUS SB7LESUMMTUS PNDPIEØIMTUS 584

PIEUMMTUS ABZEVEØ1MTUS U85LESøZMTUS A86LESø3

DATASENS: $N$ BOUNDARIES: $Y$ PHOTOS: $Y$ DWNERINFO: $Y$

TRANSCRIBR: 87-12-18 JSS CDREV: $Y$ MAPPER: 87-12-18 JSS QC: $Y$

UPDATE: $88-04-26$ J55 


\section{ELEMENT OCCURRENCE RECORD}

EOCODE: PDAPIZGø10.øळ3

NAME : SHOSHONEA PULVINATA

COMNAME: SHOSHONEA

MARGNUM: 19 TENTEN: 5,1 IDENT: Y EORANK: $B$ EORANKCOMM: REMOTE HABITAT IN GOOD CONDITION, MODERATE-SIZED POPULATION.

SURVEYDATE: 1987- $97-13$ LASTOBS: 1987-97-13 FIRSTOBS: 1987 GRANK: G2G3 SRANK: 51 STATE: MT COUNTYNAME: MTCARB

QUADCODE : $451 \varnothing 813$

QUADNAME: MYSTERY CAVE PRECISION: $\quad 5 C$

LAT: 456715 LONG: 1681991 S: $450650 \mathrm{~N}: 450722$ E: 1981804 W: 1681910 TOWNRANGE: $\emptyset 98 \varnothing 28 E$ SECTION: $2 \emptyset$ MERIDIAN: PR

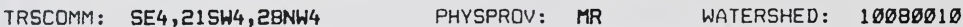

DIRECTIONS: PRYOR MOUNTAINS, ALONG RIDGES EAST OF BIG COULEE, $\emptyset .75-\emptyset .85$

AIR MILES SSE TO WSW OF MYSTERY CAVE.

GENDESC: ON EDGES OF PINUS FLEXILIS-PSEDOTSUGA MENZIESII FORESTS; ON WIND-BLASTED RIMS OF GRAVELLY, LIMESTONE-DERIVED SOILS, GENTLE NW-FACING SLOPES, WITH ASTRAGALUS ARETIOIDES, (CONT.)

ELEV: 7489 SIZE: 15

EODATA: GENDESC (CONT.): ERITRICHIUM, ASTRAGALUS, ERIGERON.

EODATA: CA. $15 \emptyset \emptyset$ PLANTS IN 3 SUBPOPULATIONS (WEST-15ø

PLANTS; CENTRAL-3פø PLANTS; EAST-2øø PLANTS); SITE IS LITTLE

THREATENED; EVIDENCE OF PAST LIVESTOCK GRAZING.

COMMENTS: VOUCHERS - LESICA, P. $(4391,4394), 1987$, MONTU.

MACODE 1: FNPNRBIGHIMTUS CONTAINED 1: N MACODE2: FBLHRPRYOIMTUS CONTAINED2: $Y$ MACODE3: FBLRABILLIMTUS CONTAINED3: N ADLMAS: $Y$ MORELAN: MOREPROT: MOREMGMT: B SITECODE :

SITENAME: MYSTERY CAVE

OWNER: U.S. BLM, NPS

OWNERCOMM:

PROTCOMM: PARTIALLY WITHIN BIGHORN CANYON NATIONAL RECREATION AREA.

MGMTCOMM:

MONITOR:

MONI TORNUM:

BESTSOURCE : LESICA, P. 1987. FIELD SURVEYS IN CARBON COUNTY OF 8-13 JULY.

SOURCECODE: FB7LESפ1MTUS PNDLESפ1MTUS SB7LESUMMTUS ABZEVEøIMTUS

DATASENS: $N$ BOUNDARIES: $Y$ PHOTOS: $Y$ OWNERINFO: $Y$ TRANSCRIBR: 87-12-17 JSS CDREV: $Y$ MAPPER: 87-12-18 J5S QC: $Y$ UPDATE: $88-04-26$ JSS 
$-5$

$-1$

$-3$ 
yำง 4

2) 60

Maril in (is? 